\title{
Public Acceptance of Products of Plant Biotechnology and Genetically Modified (GM) Crops (1999-upto now)
}

\author{
*Girma Gashu Kebede \\ Ethiopian institute of agriculture research \\ P.O.Box 2003; Addis Ababa, Ethiopia
}

\begin{abstract}
There is a significant gap in farmer acceptability of genetically modified plants for production in several countries throughout the world, as well as in the major markets for food, feed, and factory usage. This paper analyzes the progress of agricultural biotechnology's practical applications with different trajectories, which affect the evolution of bacterial resistance genes, viral resistance genes, and fungal resistance genes. This has also influenced the views of customers and processors. Perceptions of risks and advantages, knowledge and trust, and personal values are all key elements that influence consumer attitudes. Some customers have expressed concerns about transgenic crops as a result of the new breeding techniques; nonetheless, it is unclear how consumers' attitudes about them will evolve. If they focused less on technologies and more on common goals and values, public trust and information about agricultural biotechnology would be more fruitful.
\end{abstract}

Keywords: Agricultural biotechnology, Transgenic crops

DOI: $10.7176 / \mathrm{JNSR} / 13-1-02$

Publication date: January $31^{\text {st }} 2022$

\section{Growth of Agricultural Biotechnology}

After first transgenic plants were created in the laboratory, genetically modified food crops were introduced in common markets. The first GM plants i.e FLAVER SAVER tomato was created in the laboratory in 1994. The purpose of this GM crops was to delay the premature fruit softening. As that time this GM crops were hit the shelves of U.S grocery stores [1]. Following flavor saver tomato, insect resistance Bt Maize and Bt cotton, herbicide tolerance soya bean and oilseed rape were planted on rapidly increasing areas. According to ISAAA report, genetically modified crops were grown in 18 million farmers in 2014 in 28 countries on a total surface area of 181.5 million hectares in the world, this area coverage corresponds about $13 \%$ of worlds arable land. In 2017 the total world GM acreage was increased by 3\% which is 189.8 million hectares. Also, GM growing countries increased from 28-43. In total, 67 of the world's 195 countries have adopted biotech crops in 2021 according to ISAAA report and this is the fastest crop technology in the world achieving 112 -fold increase since its commercial introduction since 1996. This indicates GM crops were adopted fasten. In $2014,82 \%$ soya bean, $68 \%$ cotton, $30 \%$ maize and $25 \%$ seed rape were planted globally ([2]. GM plants have supplanted conventional types in many nations, where farmers have the freedom to choose which technology they want to use. The adoption rate for biotech cultivars in maize, cotton and soya bean in united states is far above $90 \%$. With herbicide tolerance sugar beet, farmers benefit from easier weed control, fewer herbicide treatments, which saves time and money, and higher earnings, which explains why so many farmers switched to the new biotech variety in such a short time [3].

\section{Reasons for Adaptation and Acceptance of Gm Plants for Farmers}

Farmers reasons for choosing biotech over traditional crop varieties have been thoroughly researched. In 2014, Klumper and Quaim published a meta-analysis of 147 agronomical research that looked at the performance of variety of GM crops in varies world areas, agricultural systems and developing and developed countries [4]. When farmers used transgenic crops, their revenues climbed by $68 \%$. Crop yields increased by $22 \%$, while pesticide costs decreased by 39 to $68 \%$. In average, developing countries reported bigger increase in yields and profit than developed once. Farmers earn financially by planting transgenic cultivars, despite the greater seed cost. Farmers frequently cite non-monetary benefits, such as time savings, simplicity of use, and increased planning flexibility, in addition to these economic benefits.

\subsection{Importance of GM Crops as Feed}

GM crops are used as feed for food producing animals in $70 \%$ to $90 \%$ of case around the world. More than $95 \%$ of food-producing animals in the united states use GM feed, thanks to widespread adoption of GM crops. This amounted to more than 100 billion animals in the last ten years alone. These animals' health and performance are continuously monitored. When this massive dataset was analyzed, no negative effects of GM feed versus conventional feed were discovered. The global demand for non-GM feed is quite low [5]. The percentage of this specialized market for soya beans is projected to be less than $4.5 \%$, while maize accounts for roughly $7 \%$ of traded commodities. Given the widespread acceptance of GM cultivars in major export countries soyabean may 
make up mor than $90 \%$ of all soyabeans shipped globally.

\subsection{Importance of GM Crops as Food}

Some benefits of genetic engineering in agriculture are increase crop yields, reduced costs for food or drug production, reduced need for pesticides, enhanced nutrient composition, and food quality and resistance pests and disease, greater food security and medical benefits to the worlds growing population. Advance have been made in developing crops that mature faster and tolerate aluminum, boron salt, drought, frost and other environmental stress, allowing plants to grow in conditions where they might not otherwise flourish [6].

\section{Gm Crops in Africa}

Four African countries have commercially grown genetically modified (GM) crops: south Africa, Burkina Faso, Egypt and Sudan [7]. South Africa has been the leading grower of GM crops since 1999, with Burkina Faso and Egypt following suit in 2008. Sudan grew genetically modified cotton in 2012. Other countries are doing trial and research on crops essential to Africa with the help of forging governments and foundations. Cotton, maize, casava, cowpea, sorghum, potato, banana, sweet potato, sugarcane, coconut, squash, and grape are among the crops being studied for usage in Africa. In a study of voluntary labeling in south Africa, it was discovered that $31 \%$ of items labeled as GMO-free or had a GM concentration of more than $1 \%$. According to research conducted in Uganda in 2011, transgenic banana has a strong potential to relive rural poverty, while urban customers with a better income may reject their adoption [7].

\section{Gm in Europe}

Only one GM plant i.e insect resistance insect maize MON10, is approved for production in the EU due to a stringent regulatory environment. Spain is the only European country, where this GM crop is widely planted. Since its debut in 1998, farmers have had positive experience with Bt maize's effectiveness in combating the corn borer in infested areas, as well as its economic performance. Meanwhile, Bt maize is grown on more than $30 \%$ of the total Spanish maize land [8]. A small proportion of Bt maize is grown in four other EU nations (Portugal Cech Republic, Romania, and Slovakia). However, Europe's overall GM crop planting of 143,000 hectares in 2014 represent only a small portion of the global GM crop acreage. Starting in 1999, farmers in Romania were able to produce herbicide tolerant GM soyabeans, which provide them with additional weed control options, boosted average yields by over $30 \%$, and made this crop the most profitable arable crop in Romania. In 2006, 137,000 hectare of GM soya varieties were planted, with a $68 \%$ acceptance rate relative to the entire soya production area. Romania soya production skyrocketed as a result of greater yield and planting, allowing surplus soybeans to be sold to other European countries while soyabean meal imports plummeted.

\section{GM Crops in USA}

USA is the most GM producing countries in the world. It led first in all aspects of genetically modified organism (GMO). Today there are $10 \mathrm{GM}$ crops currently produced in the US while more than $120 \mathrm{GM}$ seeds with unique traits have been deregulated. More than $90 \%$ of corn, soyabean, cotton and canola and sugar beet acreage in the USA in GMO [9].

\section{GM Crops in The World}

The GM crops grown commercially included: potato (USA), pumpkin, alfalfa (USA), sugar beet (USA and Canada), papaya (USA and China), oilseed rape (4 countries), maize (17 countries), soya beans (11 countries) and cotton (15 countries) were grown in 2020 according to $I S A A A$ reports. 


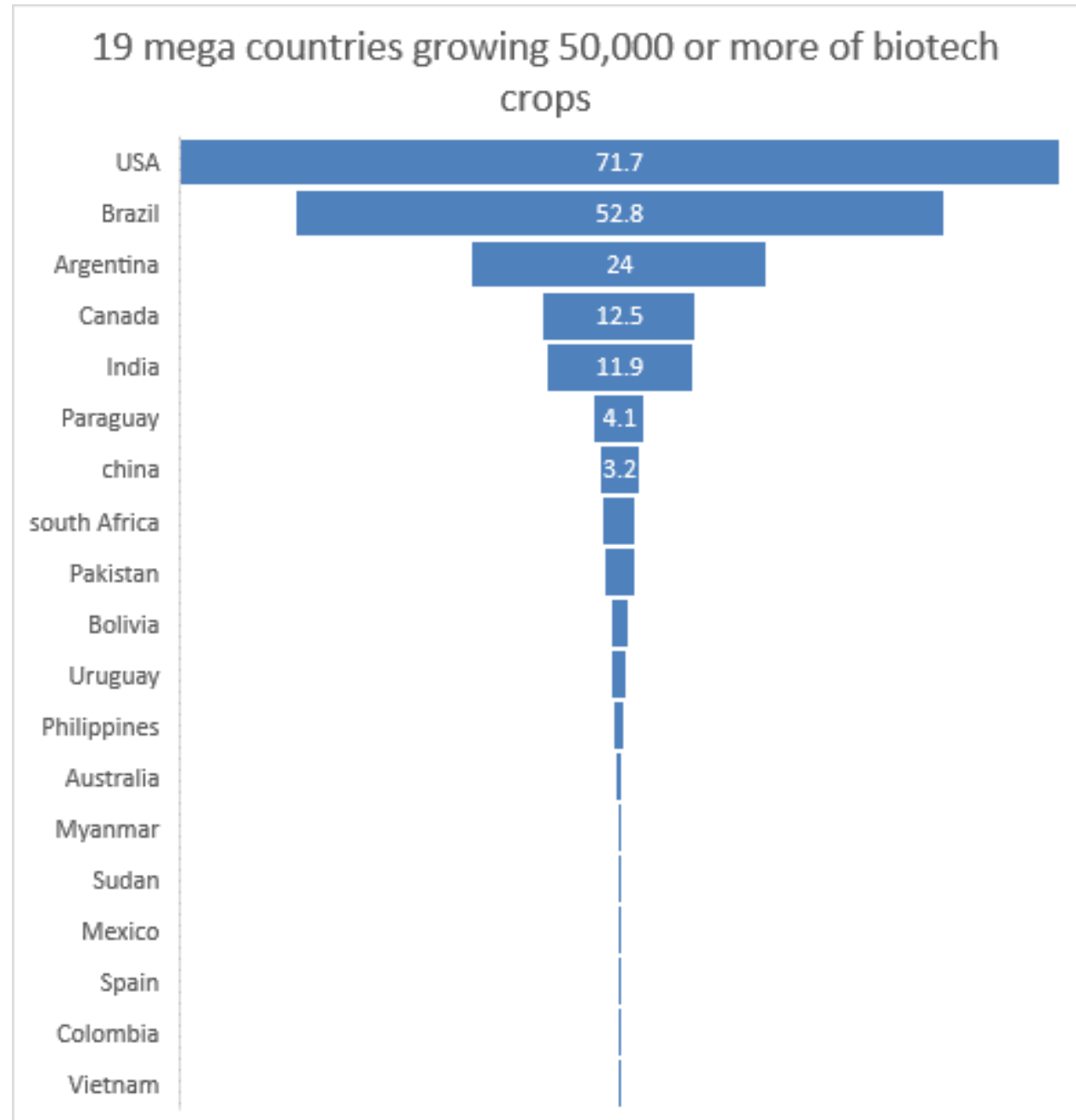

Fig. 1. Area of genetically modified (GM) crops worldwide in 2020 by country (million hectares) Source: ISAAA

\section{Factors Affecting Consumer Attitudes Towards GM Food}

The use of genetically modified plants as food or feed is particularly sensitive topic. Many academics have investigated the factors that influences consumers perceptions and the evolutions of their attitudes towards new technology and genetically modified foods, using various techniques. Food is a significant topic for many consumers because it is a vital feature of daily living. As a result, new food technologies are scrutinized closely and frequently received with skepticism a phenomenon known as "food neophobia" [10].

\section{Perceptions of Risk and Benefits}

Consumers behaviors are influenced by risk and reward perception [11]. Despite the obvious benefits of genetically modified crops to farmers, which have propelled their wide spread adoptions over the previous two decades. These benefits are not perceived by consumers [12]. Indeed, the great majority of today's GM crops feature agricultural "inputs qualities" like insects' resistance or herbicide tolerance that make farming easier for farmers but have no discernible effects on food quality or attributes. The large-scale cultivations of GM crops have considerable positive impact on world welfare. The net economic benefit at the farm level alone were estimated to be $\$ 18.8$ billion in 2012[13], but the total economic benefit is distributed among farmers, seed and technology provides, and consumers, with the later receiving a significant portion (in many cases more than half) of the total benefit. Consumers, on the other hand, may be concerned about the potential negative health impacts of GM food, the effects of consuming "foreign" DNA, and un expected changes in nutritional quality or allergenicity.

\section{Knowledge and Trust}

\subsection{Institutionalized A Verified Information System}

An ideal verified information system for agricultural biotechnology would include a mechanism for disclosing 
private information (i.e., information for knowledge that exist but is not accessible to everyone), a process for refuting or confirming claims made by interested parties, and a process for expanding the stock of knowledge about the short- and long-term effects of biotechnology [14]. Because agricultural biotechnology is a global, multigenerational public good, the challenge is immense. On a global scale, biotech knowledge is non- viral and non-excludable, despite the facts that certain process and products have been made in to impure public goods through the use of parenting and international patent agreements.

\subsection{Trust in Public Institution}

A verified biotechnological information system requires public funding. Because it will almost certainly run by one or more government bodies. The public trust is required for this institutional architecture to be succeed. Currently, the amount of faith or confidence that the public places in information provided by national government bodies dealing with similar concerns in western industrialized countries varies. Public trust in the united states is strong, where as it is low in western European countries and very low in Africa. Gaskell et al (1999) reported in public opinion poll in united states that found a high level of trust in USDA and FDA information on biotechnology safety. He reported on study of the public in 17 European countries, finding poor public trust in national governmental authorities to "tell the truth about GM crops growing in fields". But now a days, it has become increasingly obvious that the information system focused just on the fact fail to persuade many consumers of the benefits of genetically modified foods. Information material regarding to food biotechnology and product example with health and sustainability benefits failed to improve the general attitude of customers in large-scale experiment with European consumers, and product choice was even influenced negatively [15].

\subsection{Personal Attitude, Values and Psychological Factors}

A complex and deeply established set of personal values and attitudes influence how people perceive new food technologies. The personal value of a products naturalness appears to be a significant element. When customers have strong desire for organic food and natural food production, new food technology are seen more unfavorably [16]. Attitudes towards nature, technology, skepticism towards new types of food, fleeing of stringent from the market place, and the evolution of once own knowledge all influence how factual information is perceived and processed, resulting in varied consequences depending on the preexisting value set [17]. Cultural value such as an aversion to being invaded or dominated by foreign food culture ("slow food" as opposed to "fast food"), as well as conflict with religious or moral belief system, or the perceived natural order of things, all influence human views towards GM crops and food. Furthermore, personal world views have an impact on how dangers are perceived. Many customers are also concerned about their financial situation. They are concerned about patenting, the negative effects of GM crops on small farmers and their potential contribution to global inequality, the growing influence of multinational corporations on the food supply, or the perception that large corporations are the primary beneficiaries of agricultural biotechnology, while the consumer bears the risk.

\section{The Future of Gm Food Plants}

The first-generation GM crop plants are now being expanded and modified well. Crops with stacked characteristics are being developed by biotechnology companies (referring to the transformation of target crops with multiple genes). Herbicide and insect resistance are sometimes expressed in the same GMO lines, giving farmers the option of growing crops with both traits. This is one type of gene "staking". Stacking, on the other hand has been employed to combat plant and insect predator genetic resistance. The wide spread uses of insect and weed-resistance GM crops in the united states has unavoidable resulted in the establishment of genetic resistance in the target species, weeds and insect predators. For example, Biotech companies are working on GMO lines that produce a variety of distinct mutations in the gene that encodes the protein that targets insects feed on GMO plants. This is likely to delay the developments of genetic resistance, in insects but it does not address the problems underline issue of sustainability [18].

Improvement and alterations in crop plant quality parameters are among the quality being incorporated into the next or "second generations of GM agricultural plants". This is a departure from the biotechnology industries original objectives. Changes/improvements in the nutrition offered by the harvested portions of the crop plants are among this quality parameters. Furthermore, the biotechnology industries' ambitions have included attempting to cope with complex characteristics (those impacted by several genes) that affect a crop plants ability to efficiently employ production imputes. Drought tolerance and nitrogen use efficiency are two of these features. We are starting to see commercial release of GMO crop lines with some of these second-generation characteristics as early as 2017 . This method has resulted in the development of an alfalfa variety with less lignin and consequently increased animal digestion. Several decades ago, disease resistance in papaya was one of the first applications of GMO technology. However, GMO technology is being used to boost crop plant tolerance to plant pathogens that cause significant disease. Potato, plum and squash are among the crop plants that have been 
genetically modified to with stand viruses. The USDA has approved three key commercial potato varieties that have a gene from a wiled species related to farmed potato that increase resistance to the fungal illness, late blight, which has been known since the late $19^{\text {th }}$ century European potato famine [18]. Crop plants can also be employed as "bio factories" for the production of critical medications. Some believes this, as well as other novel applications of genetic engineering to plants, to be the third generation of GMO technological development. Its unknown whether or if this use of genetic engineering will be embraced, an if so, to what extent.

\section{Projections of How Emerging Genetic Engineering Technology Will Affect Trait Development}

Because of the following three paradigm-shifting capabilities in accuracy, complexity and variety, the new genetic engineering technologies mentioned have the potential to significantly alter future output in terms of quality, quantity, and applications.

\subsection{Increase Precision of Genome Alteration and Gene Insertion}

The majority of commercially available GM crops in 2015 were created by agrobacterium tumefaciens-mediated or gene-gun mediated transformation, both of which resulted in DNA insertion into semirandom place in the genome. Because of positional effects that rely on where the DNA was placed in the genome, variation in transgene expression was commonly found; this necessitated screening of large numbers of GE plants to select the best transgenic individuals. Emerging technologies allow for insertion into precise genomic sites that are chosen to allow for proper expression [18].

\subsection{Increase Complexity of Genomic Changes}

Because multiple genes can be introduced or "stacked" in to a single target locus in which genes (transgenes, native genes, cis genes) are inserted as a "cassette" in to the target locus, emerging genetic engineering technology have the potential to significantly increase the complexity of engineered changes. Future GE crops are likely to use new paradigms, such as several genes for one feature, multiple genes for multiple traits, or, in certain circumstance, one gene for numerous traits. The capacity to introduce numerous genes broadens the range of possibilities for modifying plants native metabolic process (metabolic engineering). Metabolic engineering can be simple (modifications of a simple gene to modify flux in an existing route) or complicated (modifications of many genes to affect flux in numerous pathways) (multiple genes manipulated to introduce a new pathways). Synthetic biology is a method that involves using many genes from different organisms that have been changed or manufactured from scratch outside of the organisms of origin [18]

\subsection{Increased Diversity of Engineered Crops Traits}

The range of crops and traits that will be created is perhaps the most significant change brought about by emerging genetic engineering technologies. Also commercialized GE crops were primarily high-production commodity crops (maize, soyabean, and cotton) until 2015, the committee anticipates an increase in genetically engineered crop species as well as an expansion of crop genetic engineering applications for food, feed and human health [18].

\section{Conclusion}

Different circumstance must be distinguished when considering customers acceptance of GM crops. Seed firms and distributers serve farmers as consumers. Biotech seed adoption and acceptance of GM crops in many world regions is very high due to clear benefit to them. Furthermore, GM plant varieties mostly used as feed are widely accepted in international commodity commerce, while certified non-GM crops are a niche industry. Consumers in many nations, on the other hand, are skeptical about the hazards and benefits of genetically modified crops and foods, and declared acceptance of GM food products is low, particularly in Europe. Consumers attitudes are shaped by a complex collection of personal values, to a considerable extent, predetermine how external information is processed, including information, trust, beliefs, risk and benefit perceptions, and evolve against the backdrops of a complex set of personal values. As a result, rejecting genetically modified plants and goods generated from them is frequently not based only on well-defined consideration, but also, GM crops have become a lightning rod for negative emotions triggered by everything that is wrong with modern agriculture and the food system, concerns about the individual place in a society, feeling of limited individuals selfdetermination versus the growing influence of large corporation, and worries about misguided economic developments, globalization, and growing inequality.

Both conventional breeding and genetic engineering are complementary approaches to crop development, and employing both will yield more progress in crop development than using either alone. Also, some complex features are unlikely to be introduced with out genetic engineering, a better understanding of the genetic basis of complex traits such as drought tolerance and nitrogen use efficiency will necessitate basic research investment in both approaches. It is vital that investment in genetic engineering solutions do not detract from investments in 
other technologies that have previously been proved to promote sustainable crop yield and nutrition.

\section{Reference}

1. Bruening, G.; Lyons, J.M. the case of FLAVER SAVER tomato. Calif. Agric. 2000, 54, 6-7. [crossRef]

2. James, C. Global status of commercialized Biotech/GM crops: 2014; ISAAA Bries. ISAAA: Ithaca, NY, USA, 2014.

3. Dillen, K.; Demont, M.; Tillie, P.; Rodriguez Cerezo, E. Bred for Europe but grown in America the case of GM sugar beet. New Biotechnol.2013, 30, 131-135. [crossRef] [PubMed].

4. Klumper, W.; Qaim, M. A meta-analysis of the impacts of genetically modified crops. PLoS ONE 2014, 9, e111629. [crossRef] [PubMed].

5. Van Eenennaam, A.L.; Young, A.E. prevalence and impacts of genetically engineered feedstuffs on livestock population. J.Anim.Sci.2014, 92, 4255-4278. [CrossRef] [PubMed].

6. Takeda, S., and Matsuoka, M. Genetic approaches to crop improvement: Responding to environmental and population changes. Nature Reviews Genetics 9, 444-457 (2008) doi:10.1038/nrg2342 (link to article)

7. Plant genetic engineering in Africa. African farming. Retrieved 2017-06-05.

8. Gomez-Barbero, M.; Berbel, J.; Rodriguez-Cerezo, E. Bt corn in spain- the performance of the EU's first crop. Nat. Biotechnol. 2008,26,384-386. [CrossReff] PubMed]

9. James Clive. (2015). Global status of commercialized biotech/GM crops. ISAAA. Brief no. 51.

10. Siegrist, M. factors influencing public acceptance of innovative food technologies and products. Trends food Sci. technol. 2008, 19 603-608. [CrossRef].

11. Frewer, L.J.; van der Lans, I.A.; Fischer, A.R.H.; Reinders, M.J.; Menozzi, D.; Zhang, X; Van den Berg, I.; Zimmermann, K.L. public perceptions of agri-food applications of genetic modification: a systemic review and meta-analysis. Trends Food Sci. technol.2013, 30, 142-152. [CrossRef].

12. Batista, R.; Oliveira, M.M. facts and fictions of genetically engineered food. Trends Biotechnol.2009, 277286. [CrossRef] [PubMed]

13. Qaim, M. the economic of genetically modified Crops. Annu. Rev. Resour. Econ. 2009,1, 665-694. [CrossRef].

14. Fernandez-Cornejo, J.; Wechsler, S.; Livingston, M. Mitchell Genetically engineered crops in the united states; USDA economic research service: Washington, DC, USA, 2014.

15. Scholderee, J.; Frewer, L.J. The biotechnology communication paradox: experimental evidence and the need for a new strategy. J. Consum. Policy 2003, 26, 125-157. [CrossRef].

16. Siegrist, M. Factors influencing public acceptance of innovative food technologies and products. Trends food Sci. Technol. 2008. 19, 603-608. [CrossRef].

17. Grunert, K.G.; Bredahl, L.; Scholderer, J. four questions for eropean consumers attitude towards the uses of genetic modifications in food production. Innov. Food Sci. Emerg. Technol. 2003,4,435-445. [CrossRef].

18. National academies of science, engineering, and medicine; division on earth and life studies; board on agriculture and natural resource; committee on genetically engineered crops: past experience and future prospects. Genetically engineered crops: experience and prospects. Washington: national academies press (US); 2016 may 17. Future genetically engineered crops. Available from: http://www.ncbi.nlm.nih.gov/books/NBK424554/. 